\title{
Outcomes of arterial switch operation for Taussig-Bing anomaly versus transposition of great arteries and ventricular septal defect
}

\author{
Büyük arterlerin transpozisyonu ve ventriküler septal defekte klyasla Taussig-Bing anomalisinde \\ arteriyel switch operasyonunun sonuçları
}

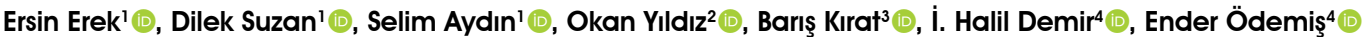

Institution where the research was done:

Acıbadem Mehmet Ali Aydınlar University School of Medicine, Istanbul, Turkey

Author Affiliations:

'Department of Pediatric Cardiac Surgery, Acıbadem Mehmet Ali Aydınlar University School of Medicine, Istanbul, Turkey 2Department of Pediatric Cardiac Surgery, Istanbul Mehmet Akif Ersoy Thoracic and Cardiovascular Surgery Training and Research Hospital, Istanbul, Turkey ${ }^{3}$ Department of Anesthesiology and Reanimation, Acıbadem Atakent Hospital, Istanbul, Turkey ${ }^{4}$ Department of Pediatric Cardiology, Acıbadem Atakent Hospital, Istanbul, Turkey

\begin{abstract}
Background: This study aims to present the outcomes of arterial switch operation for Taussig-Bing anomaly versus transposition of the great arteries and ventricular septal defect.

Methods: Between November 2010 and December 2016, a total of 100 consecutive arterial switch operations in 42 pediatric patients (25 males, 17 females; median age 17 days; range, 2 to 210 days) were performed in two centers. Among them, 42 patients had associated ventricular septal defect and were diagnosed with Taussig-Bing anomaly $(n=15)$ or transposition of the great arteries and ventricular septal defect $(n=27)$. Aortic arch anomalies were present in six patients $(40 \%)$ with Taussig-Bing anomaly and two patients (7.4\%) with transposition of the great arteries and ventricular septal defect $(\mathrm{p}=0.016)$. Coronary anomaly was observed in five $(33.3 \%)$ and six $(22.2 \%)$ patients, respectively. All patient had a large defect (multiple $n=4$ ), except for eight patients who had moderate defect in the transposition of the great arteries group.

Results: Early mortality was $13.3 \%$ in the Taussig-Bing anomaly group and $7.4 \%$ in the other group. Extracorporeal membrane oxygenation support was needed in three patients. Delayed sternal closure was used in most of the patients $(92.9 \%)$. The median length of intensive care unit and hospital stays were similar between the groups. The median follow-up was 16 (range, 1 to 50) months. Two patients including one planned (debanding and multiple defect closure) and one unplanned (residual defect closure) were reoperated. Three patients needed aortic balloon angioplasty due to recoarctation and one patient underwent pulmonary balloon angioplasty. Overall reintervention rate was $18.4 \%$.
\end{abstract}

Conclusion: Although the incidence of aortic arch and coronary anomalies were higher in patients with Taussig-Bing anomaly, early and mid-term results were similar. Based on these results, primary arterial switch operation seems to be successfully performed for both pathologies.

Keywords: Congenital heart disease, neonate, Taussig-Bing anomaly, transposition of great arteries, ventricular septal defect.

\section{$\ddot{o} Z$}

Amaç: Bu çalışmada büyük arterlerin transpozisyonu ve ventriküler septal defekte kıyasla, Taussig-Bing anomalisinde arteriyel switch operasyonunun sonuçları sunuldu.

Çalışma planı: Kasım 2010 - Aralık 2016 tarihleri arasında iki merkezde 42 pediatrik hastaya ( 25 erkek, 17 kız; medyan yaş 17 gün; dağılım, 2-210 gün) toplam 100 ardışık arteriyel switch operasyonu yapıldı. Bunların arasında 42 hastada ilave ventriküler septal defekt mevcuttu ve Taussig-Bing anomalisi $(n=15)$ veya büyük arterlerin transpozisyonu ve ventriküler septal defekt $(\mathrm{n}=27)$ tanısı kondu. Taussig-Bing anomalisi olan altı hastada (\%40) ve büyük arterlerin transpozisyonu ve ventriküler septal defekt olan iki hastada (\%7.4) arkus aorta anomalileri mevcuttu $(\mathrm{p}=0.016)$. Sırasıyla beş $(\% 33.3)$ ve altı hastada $(\% 22.2)$ koroner anomali izlendi. Büyük arterlerin transpozisyonu grubunda orta büyüklükte defekt olan sekiz hasta hariç, hastaların tümünde geniş çaplı defekt vardı (çoklu n=4).

Bulgular: Erken mortalite Taussig-Bing anomalisi grubunda \%13.3 ve diğer grupta \%7.4 idi. Üç hastaya ekstrakorporeal membran oksijenasyon desteği gerekti. Hastaların çoğuna (\%92.9) gecikmiş sternum kapatılması uygulandı. Medyan yoğun bakım ünitesi ve hastane kalış süreleri gruplar arasında benzerdi. Ortanca takip süresi 16 (dağ $11 ı m, 1-50)$ ay idi. Biri planlı (debanding ve çoklu defekt kapatılması) ve biri plansız (rezidüel defekt kapatılması) olmak üzere iki hasta yeniden ameliyat edildi. Üç hastada rekoarktasyon nedeniyle aortik balon anjiyoplasti ve bir hastada pulmoner balon anjiyoplasti gereksinimi oldu. Genel yeniden girişim oran $1 \% 18.4$ idi.

Sonuç: Taussig-Bing anomalisi olan hastalarda arkus aorta ve koroner anomalilerin görülme sıklığı daha yüksek olsa da, erken ve orta dönem sonuçlar benzerdi. Bu sonuçlara göre, primer arteriyel switch operasyonu her iki patolojide de başarılı bir şekilde uygulanabilir.

Anahtar sözcükler: Doğuştan kalp hastalı̆̆ı, yenidoğan, Taussig-Bing anomalisi, büyük arterlerin transpozisyonu, ventriküler septal defekt.

\section{Received: September 30, 2018 Accepted: February 28, 2019 Published online: June 19, 2019}

Correspondence: Ersin Erek, MD. Acıbadem Mehmet Ali Aydınlar Üniversitesi Tıp Fakültesi, Çocuk Kalp ve Damar Cerrahisi Anabilim Dalı, 34752 Ataşehir, İstanbul, Turkey. Tel: +90 212 - 4044278 e-mail: ersinerek@gmail.com ventricular septal defect. Turk Gogus Kalp Dama 2019;27(3):266-273 
Taussig-Bing anomaly (TBA) is a rare congenital cardiac malformation which was first described in 1949 by Helen B Taussig and Richard J. Bing ${ }^{[1]}$ as a double-outlet right ventricle (DORV) with side-by-side position of the great arteries in which both the aorta and the pulmonary artery arise entirely from the right ventricle and are supported by bilateral coni..$^{[2]}$ The arterial switch operation (ASO) has become the procedure of choice for treatment of TBA, as well as transposition of the great arteries (TGA) with or without a ventricular septal defect (VSD). ${ }^{[3,4]}$

Taussig-Bing anomaly continues to pose a considerable surgical challenge, related to associated anomalies, varying degrees of right ventricular outflow tract and aortic arch obstruction caused by a malaligned ventricular septum. ${ }^{[4,5]}$ Although banding of the pulmonary artery was the usual initial palliative procedure in the past, primary ASO with VSD closure with or without aortic arch repair is the gold standard in the current practice. Patients with TBA are usually considered to have an increased mortality and morbidity, compared to those with TGA+VSD following ASO. ${ }^{[4]}$

Previous studies have demonstrated significant rates of reintervention, mortality, and neoaortic complications in both pathologies. ${ }^{[5,6]}$ In the present study, we aimed to present our early and mid-term outcomes of ASO for TBA versus TGA+VSD and to identify predictors for mortality and reintervention.

\section{PATIENTS AND METHODS}

Between November 2010 and December 2016, a total of 100 consecutive ASO were performed in two centers. Among them, 42 patients had associated VSD and were diagnosed with TBA $(n=15)$ or TGA+VSD $(n=27)$. Median age was 17 days (range, 2 to 210 days). Twenty five of them were males and 17 females. Those with a small VSD not requiring surgical closure during ASO were excluded. The study flow chart is shown in Figure 1. Data including demographic and clinical characteristics of the patients were retrospectively reviewed. A written informed consent was obtained from each parent. The study protocol was approved by the Acrbadem Mehmet Ali Aydınlar University School of Medicine Ethics Committee (ATADEK-2018-13/8). The study was conducted in accordance with the principles of the Declaration of Helsinki.

\section{Operative technique}

A standard ASO was performed under moderate hypothermic $\left(26\right.$ to $28^{\circ} \mathrm{C}$ ) cardiopulmonary bypass
(CPB) with bicaval cannulation. Intermittent tepid blood cardioplegia was used for myocardial protection. Coronary artery buttons were excised from the aorta and reimplanted using the trap-door technique. After the Lecompte's maneuver, the neopulmonary root was reconstructed with two separate patches of glutaraldehyde-treated autologous pericardium. All VSD closures were performed via trans-neoaortic approach in 11 patients $(73.3 \%)$ in TBA group, while others had transatrial approach. Pericardial patch closure (either with interrupted or continuous $6 / 0$ or $7 / 0$ prolene sutures) was applied to most of the patients, except seven patients who had a moderate VSD and underwent primary VSD closure in the TGA+VSD group. One patient in each group needed additional pulmonary banding due to multiple VSDs. In the patients with aortic arch obstruction, aortic arch repair was performed initially. Aortic cannula was advanced into the innominate artery. The innominate artery was snared and selective cerebral perfusion was used during aortic arch repair. In certain cases with distal arch obstruction, an aortic clamp was applied to the distal of the innominate artery and repair was performed under selective cerebral and coronary perfusion on a beating heart. All visible ductal tissues were excised, and the proximal arch and the distal aorta were anastomosed posteriorly and usually augmented with a pericardial patch.

\section{Statistical analysis}

Statistical analysis was performed using the Number Cruncher Statistical System (NCSS) 2007 software (NCSS LLC., Kaysville, UT, USA). Descriptive data were expressed in mean \pm standard deviation (SD), median (min-max), or number and frequency. The Mann-Whitney U test was used to analyze significant differences and quantitative data between the groups. The Pearson's chi-square test, Fisher-Freeman-Halton

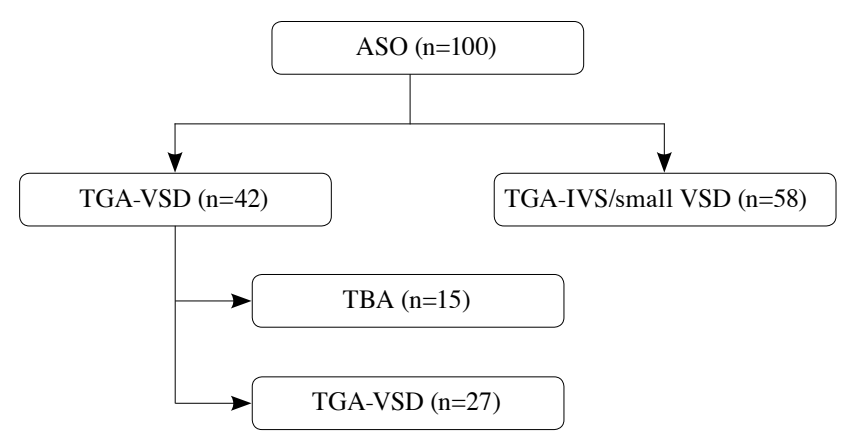

Figure 1. Study flow chart.

ASO: Arterial switch operation; TGA: Transposition of the great arteries; VSD: Ventricular septal defect; IVS: intact ventricular septum; TBA: Taussig-Bing anomaly; 


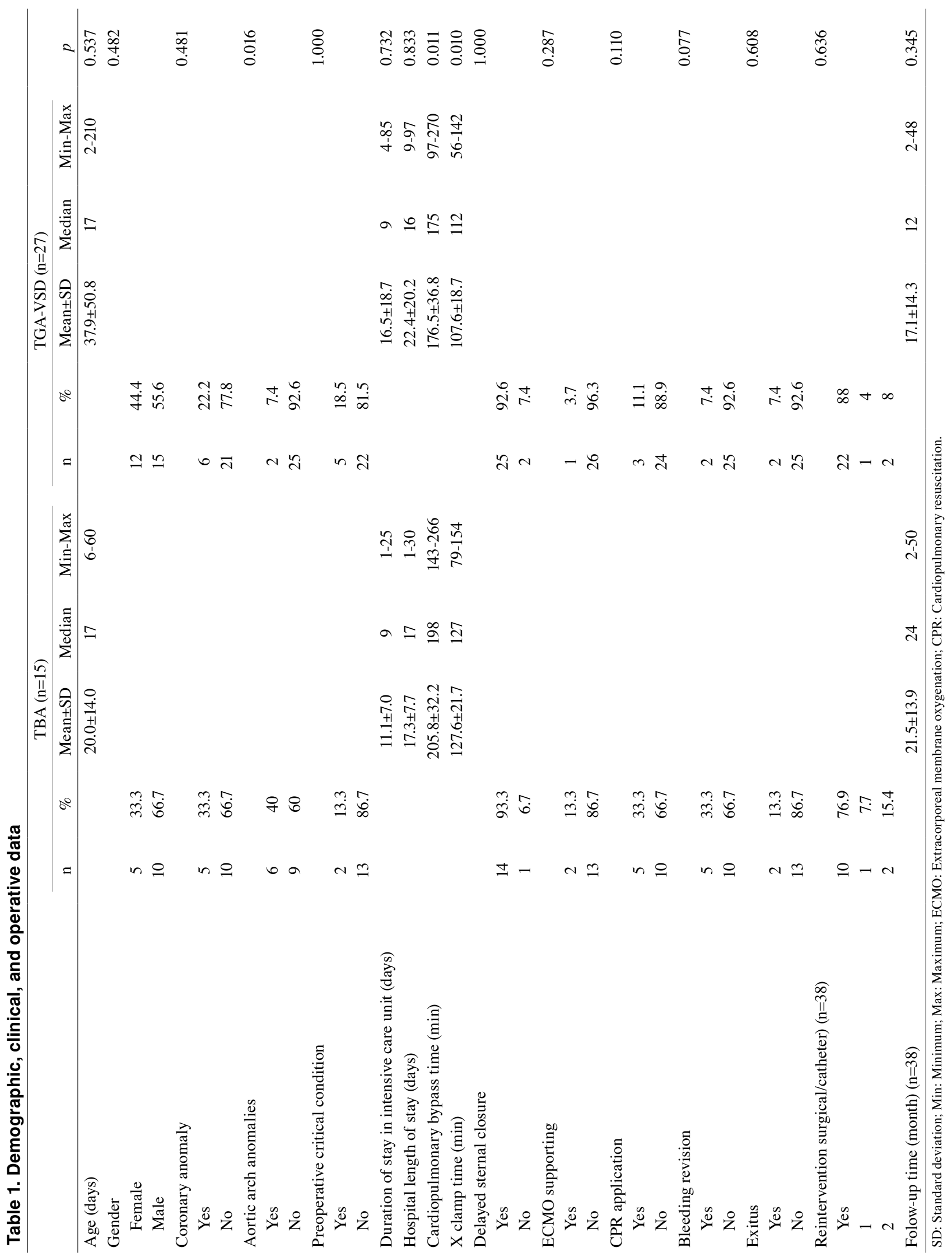


test, and Fisher's exact test were used to compare qualitative data. A $p$ value of $<0.05$ was considered statistically significant.

\section{RESULTS}

Of all patients, 34 (80.9\%) were neonates. Only one patient had previous palliative surgery with pulmonary artery banding and atrial septectomy in the TGA+VSD group in an external center. Early mortality was $13.3 \%$ in the TBA group and $7.4 \%$ in the TGA+VSD group. Delayed sternal closure was used in most of the patients (92.9\%). There was no statistically significant difference in demographic characteristics of the patients. Demographic, clinical, and operative data are shown in Table 1.

Six patients had associated aortic arch obstruction (aortic coarctation $\mathrm{n}=4$; aortic interruption $\mathrm{n}=2$ ) in TBA group (40\%), and two patients had aortic coarctation in TGA+VSD group $(7.4 \%)(\mathrm{p}=0.016)$. Coronary anomaly was present in five (33.3\%) and six (27.2\%) patients, respectively. All VSDs were large in size and subpulmonary, except for one with multiple VSDs in the TBA group. However, VSDs were large in $14(51.8 \%)$ (multiple VSDs, $n=3$ ) and moderate in eight patients (29.6\%) in TGA+VSD group. Localization and size of VSDs and types of interventions are presented in Table 2.

Extracorporeal membrane oxygenation (ECMO) support was required in three patients $(7.1 \%)$ including two in TBA group and one in TGA+VSD group.
Two patients were weaned from ECMO support and one was discharged without any significant sequelae. Five patients $(33.3 \%)$ in TBA and three $(11.1 \%)$ in TGA+VSD group experienced cardiac arrest during the postoperative course and were resuscitated. The majority of the events developed within the postoperative 48 hours.

Only one patient $(2.3 \%)$ with a primary VSD closure for a moderate VSD in TGA+VSD group needed permanent pacemaker implantation due to complete heart block. Five patients (33.3\%) in TBA group and two patients (7.4\%) in TGA+VSD group needed reexploration for bleeding.

The median duration of $\mathrm{CPB}$ and aortic crossclamp were significantly higher in TBA group (198 vs. $175 \mathrm{~min}$ and 127 vs. $112 \mathrm{~min}$, respectively; $\mathrm{p}=0.011$ and $\mathrm{p}=0.010$ ). There was no statistically difference in the length of the intensive care unit (ICU) and hospital stays between the groups.

\section{Follow-up}

All patients underwent echocardiographic examination in the early postoperative period and before discharge. Two patients had moderate (50 and $55 \mathrm{mmHg}$ gradient) peripheral pulmonary stenosis. The mean follow-up was $21.5 \pm 13.9$ months in TBA group and $17.1 \pm 14.3$ in TGA+VSD group.

One patient with coronary anomaly (1RLCx with intramural course) in TBA group died from left ventricular dysfunction in the postoperative first day.

Table 2. Localization and size of ventricular septal defects and types of intervention

\begin{tabular}{|c|c|c|c|c|}
\hline & \multicolumn{2}{|c|}{ TGA+VSD group $(n=27)$} & \multicolumn{2}{|c|}{ TBA group $(n=15)$} \\
\hline & $\mathrm{n}$ & $\%$ & $\mathrm{n}$ & $\%$ \\
\hline \multicolumn{5}{|c|}{ Ventricular septal defect location } \\
\hline Perimembranous & 21 & 77.7 & - & 0 \\
\hline Subpulmonic & - & 0 & 15 & 93.3 \\
\hline Inlet & 2 & 7.4 & - & 0 \\
\hline Apical & 1 & 3.7 & - & 0 \\
\hline Multiple & 3 & 11.1 & 1 & 6.6 \\
\hline \multicolumn{5}{|c|}{ Ventricular septal defect size } \\
\hline Large & 19 & 70.3 & 14 & 100 \\
\hline Medium & 8 & 29.6 & - & 0 \\
\hline \multicolumn{5}{|c|}{ Ventricular septal defect closure } \\
\hline Transatrial & 27 & 100 & 4 & 26.6 \\
\hline Transneoaortic & 0 & 0 & 11 & 73.3 \\
\hline Pericardial patch & 20 & 74.0 & 15 & 100 \\
\hline Primary & 7 & 25.9 & 0 & 0 \\
\hline
\end{tabular}

TGA: The great arteries; VSD: Ventricular septal defect; TBA: Taussig-Bing anomaly. 
Table 3. Correlation analysis for risk factors of early mortality

\begin{tabular}{|c|c|c|c|c|c|c|c|c|c|c|c|}
\hline & & & Exitus $(+)($ & $=4)$ & & & & Exitus (-) (n & $=38)$ & & \\
\hline & $\mathrm{n}$ & $\%$ & Mean \pm SD & Median & Min-Max & $\mathrm{n}$ & $\%$ & Mean \pm SD & Median & Min-Max & $p$ \\
\hline Age (day) & & & $36.0 \pm 20.9$ & 33.5 & $17-60$ & & & $31.0 \pm 43.9$ & 16 & $2-210$ & 0.157 \\
\hline Gender & & & & & & & & & & & 1.000 \\
\hline Female & 2 & 50 & & & & 15 & 39.5 & & & & \\
\hline Male & 2 & 50 & & & & 23 & 60.5 & & & & \\
\hline Coronary anomaly & & & & & & & & & & & 1.000 \\
\hline Yes & 1 & 25 & & & & 10 & 26.3 & & & & \\
\hline No & 3 & 75 & & & & 28 & 73.7 & & & & \\
\hline Aortic arcus anomalies & & & & & & & & & & & 0.572 \\
\hline Yes & 0 & 0 & & & & 8 & 21.1 & & & & \\
\hline No & 4 & 100 & & & & 30 & 78.9 & & & & \\
\hline $\begin{array}{l}\text { Preoperative critical } \\
\text { condition }\end{array}$ & & & & & & & & & & & 0.532 \\
\hline Yes & 1 & 14.2 & & & & 6 & 85.7 & & & & \\
\hline No & 3 & 8.5 & & & & 32 & 91.4 & & & & \\
\hline CPB time (min) & & & $176.8 \pm 39.2$ & 185 & $127-210$ & & & $188.1 \pm 37.8$ & 189.5 & $97-270$ & 0.732 \\
\hline $\mathrm{X}$ clamp time $(\mathrm{min})$ & & & $112.8 \pm 28.6$ & 111.5 & 79-149 & & & $114.9 \pm 21.5$ & 114.5 & $56-154$ & 0.748 \\
\hline
\end{tabular}

Another patient with associated interrupted aortic arch type B in TBA group died from sepsis and multiorgan failure on postoperative Day 14. The body weight of this case was $2,900 \mathrm{~g}$ and he was under mechanical ventilation, inotropic support, and prostaglandin E1 perfusion preoperatively. One patient in TGA+VSD group experienced sudden cardiac arrest in the postoperative first day, despite stable hemodynamic course early after the operation. Although extracorporeal cardiopulmonary resuscitation was performed, this patient was unable to be weaned from ECMO. The last patient was unable to be weaned from mechanical ventilation after prolonged ICU stay and she died from sepsis. One patient in TBA group died during follow-up period due to myocarditis in the postoperative fifth month. One patient needed surgery due to residual VSD. One patient in TBA group who had pulmonary banding due to multiple VSD underwent planned reoperation and debanding and multiple VSD closure was performed. Correlation analysis revealed no risk factor for early mortality (Table 3).

Moderate $(n=3)$ to-severe $(n=1)$ neopulmonary artery stenosis developed in four patients $(n=1,7.1 \%$ in TBA and $n=3,13.6 \%$ in TGA+VSD group). One patient who had severe pulmonary stenosis underwent transcatheter pulmonary balloon angioplasty. Three patients underwent balloon aortic angioplasty due

Table 4. Follow-up and reinterventions

\begin{tabular}{lccc}
\hline & $\mathrm{n}$ & & TBA group $(\mathrm{n}=15)$ \\
\cline { 2 - 3 } Recoarctation & 1 & $\mathrm{n}$ \\
Balloon angioplasty & 1 & 2 \\
Reoperation & 1 & 2 \\
Neopulmonary stenosis & (Residual VSD closure) & (Debanding and VSD closure) \\
Balloon angioplasty & 3 & 1 \\
Follow-up & 1 & 1 \\
Neoaortic insufficiency (mild-moderate) & 2 & 1 \\
\hline TGA: The great arteries; VSD: Ventricular septal defect; NS: No statistically. & 2 & 1
\end{tabular}


to recoarctation $(\mathrm{n}=2$ in TBA and $\mathrm{n}=1$ in $\mathrm{TGA}+\mathrm{VSD}$ group). Mild-to-moderate neoaortic valve insufficiency was observed in two patients in TBA and one patient in TGA+VSD group. Overall reintervention rate was $18.4 \%$ (23\% for TBA vs. $16 \%$ for TGA+VSD group) (Table 4). All surviving patients had normal development and functional class appropriate to their ages at the end of follow-up period.

\section{DISCUSSION}

Arterial switch operation is the most commonly used technique for repair of infants born with TGA and certain forms of DORV. Although over the past three decades, the results of ASO have progressively improved owing to steady refinements in diagnostic, surgical, and perioperative management techniques, it has sustained to be a surgical challenge due to the complexity of malformations with the combination of anatomic features. ${ }^{[7,8]}$

Our current policy without exception is to perform one-stage ASO complete repair with correction of associated lesions as soon as the diagnosis of TBA and TGA+VSD with the assumption of that delaying repair increases the incidence of pulmonary vascular disease, adverse effects of hypoxemia, congestive heart failure, and size discrepancy between the great arteries. ${ }^{[6]}$ The ASO for TGA with concomitant repair of aortic anomalies through median sternotomy is currently the standard procedure in specialized centers. Overall, it carries a much lower operative risk (19 to $20 \%)^{[7]}$ than the conventional two-stage approach (31 to 64\%). ${ }^{[9]}$ Equally one should expect similar outcomes for repair of TBA, the single-stage ASO with relief of aortic arch obstruction should give overall better results than the two-staged strategy. Although the numbers are small in our series, early one-stage repair provided statistically similar early and mid-term results whether aortic obstruction was present. Survival was also similar; however, the rate of reintervention may be higher due to recoarctation.

In previous studies, the ASO has been associated with poorer outcomes in patients with TBA compared with TGA+VSD. ${ }^{[9-11]}$ Complexity of the repair, particularly caused by unusual coronary patterns, mismatched size of the great arteries, and aortic arch obstruction may contribute to higher complication, mortality and reintervention rates compared to standard form of TGA.${ }^{[9-11]}$ Recent studies have demonstrated a low rate of mortality after repair of TBA and associated cardiac lesions. $^{[4,8,12-14]}$

The present study showed that VSD types and locations were different in both groups. In our routine practice, we usually prefer trans-neoaortic approach for VSD closure in TBA. Surgical exposure is usually excellent, due to the relatively large size of the neoartic annulus. Pericardial patch closure by continuous suturing with $6 / 0$ (9 $\mathrm{mm}$ needle) or $7 / 0$ prolene is easy and rapid to perform. In our study, no patient had heart block with this technique. We believe that using fine suture materials and relatively far location of conduction tissue may explain the low rate of heart block in TBA patients.

Reintervention rates were usually higher in previous studies for TBA compared to patients with TGA. ${ }^{[11,15,16]}$ In a study, Griselli et al. ${ }^{[4]}$ reported a freedom from reoperation rate of $75 \%$ at 10 years, while this rate was $80.2 \%$ at 15 years in the study of Soszyn et al. ${ }^{[8]}$ Neopulmonary obstruction and significant neoaortic insufficiency (AI) requiring aortic valve replacement has been reported as the most frequent cause of reintervention in patients with TBA in previous studies. ${ }^{[12,17-19]}$ Prior pulmonary artery banding, which may distort and increase flow velocity across the native pulmonary valve, mismatch in size of the main pulmonary artery and the aorta, and advanced age at the time of surgery have been associated with the development of neo-AI in TBA, compared to those with TGA. ${ }^{[17]}$ In our study, median age was low (17 days) in both groups, which may explain the low rate of neo-AI.

Neopulmonary stenosis still remains the most frequent cause of reoperation after ASO with a relatively early occurrence within the first two postoperative years and as much as 10 to $20 \%$ of cases in the literature. ${ }^{[9,20]}$ Insufficient mobilization of pulmonary arteries and the LeCompte maneuver have been advocated as possible triggering factors. ${ }^{[11,22]}$ The aortic annulus, which is usually hypoplastic in patients with associated aortic arch obstruction, may be another reason for the development of neopulmonary stenosis. ${ }^{[21,22]}$ Once it develops, transcatheter interventions may provide good palliation.

The low in-hospital mortality and encouraging mid-term follow-up data indicate that TBA and TGA with VSD can be corrected in the neonatal period and early infancy through ASO, closure of VSD, and simultaneous correction of aortic arch anomalies as a one-stage procedure. Simultaneous correction of aortic arch obstruction has no detrimental influence on survival and late outcomes. Results of the present study suggest that the ASO continues to offer an excellent surgical option for infants with TGA and TBA, even in the presence of complex associated lesions. Complex coronary branching patterns were no longer associated 
with an increased risk of early death, but continued to be associated with longer ICU and hospital stays. ${ }^{[23]}$ According to our analysis, no preoperative risk factors, even preoperative critical condition, was associated for the early postoperative mortality. Large-scale studies have demonstrated that lower birth weight, right ventricular hypoplasia, and staged repair of aortic arch obstruction continue to be independent risk factors for mortality after the ASO. Ongoing assessment of risk factors and long-term follow-up of the outcome of these children are essential to evaluate the outcomes of ASO.

In the present study, we used delayed sternal closure in the majority of the patients. We believe that it provides more stable postoperative course without increasing the risk of sternal wound infections. ${ }^{[24]}$

The main limitations of this study include its relatively small sample size and retrospective nature.

In conclusion, although the incidence of aortic arch and coronary anomalies were higher in patients with Taussig-Bing anomaly, early and mid-term results were similar. Based on these results, primary arterial switch operation seems to be successfully performed for both pathologies with favorable early and mid-term results.

\section{Declaration of conflicting interests}

The authors declared no conflicts of interest with respect to the authorship and/or publication of this article.

\section{Funding}

The authors received no financial support for the research and/or authorship of this article.

\section{REFERENCES}

1. Taussig HB, Bing RJ. Complete transposition of the aorta and a levoposition of the pulmonary artery; clinical, physiological, and pathological findings. Am Heart J 1949;37:551-9.

2. Konstantinov IE. Taussig-Bing anomaly: from original description to the current era. Tex Heart Inst J 2009;36:580-5.

3. Jatene AD, Fontes VF, Paulista PP, Souza LC, Neger F, Galantier M, et al. Anatomic correction of transposition of the great vessels. J Thorac Cardiovasc Surg 1976;72:364-70.

4. Griselli M, McGuirk SP, Ko CS, Clarke AJ, Barron DJ, Brawn WJ. Arterial switch operation in patients with Taussig-Bing anomaly--influence of staged repair and coronary anatomy on outcome. Eur J Cardiothorac Surg 2007;31:229-35.

5. Mavroudis C, Backer CL, Muster AJ, Rocchini AP, Rees AH, Gevitz M. Taussig-Bing anomaly: arterial switch versus Kawashima intraventricular repair. Ann Thorac Surg 1996;61:1330-8.

6. Brawn WJ, Mee RB. Early results for anatomic correction of transposition of the great arteries and for double-outlet right ventricle with subpulmonary ventricular septal defect. J Thorac Cardiovasc Surg 1988;95:230-8.
7. Comas JV, Mignosa C, Cochrane AD, Wilkinson JL, Karl TR. Taussig-Bing anomaly and arterial switch: aortic arch obstruction does not influence outcome. Eur J Cardiothorac Surg 1996;10:1114-9.

8. Soszyn N, Fricke TA, Wheaton GR, Ramsay JM, d'Udekem $\mathrm{Y}$, Brizard CP, et al. Outcomes of the arterial switch operation in patients with Taussig-Bing anomaly. Ann Thorac Surg 2011;92:673-9.

9. Masuda M, Kado H, Shiokawa Y, Fukae K, Kanegae Y, Kawachi Y, et al. Clinical results of arterial switch operation for double-outlet right ventricle with subpulmonary VSD. Eur J Cardiothorac Surg 1999;15:283-8.

10. Wernovsky G, Mayer JE Jr, Jonas RA, Hanley FL, Blackstone EH, Kirklin JW, et al. Factors influencing early and late outcome of the arterial switch operation for transposition of the great arteries. J Thorac Cardiovasc Surg 1995;109:289-301.

11. Haas F, Wottke M, Poppert H, Meisner H. Long-term survival and functional follow-up in patients after the arterial switch operation. Ann Thorac Surg 1999;68:1692-7.

12. Wetter J, Sinzobahamvya N, Blaschczok HC, Cho MY, Brecher AM, Grävinghoff LM, et al. Results of arterial switch operation for primary total correction of the TaussigBing anomaly. Ann Thorac Surg 2004;77:41-6.

13. Rodefeld MD, Ruzmetov M, Vijay P, Fiore AC, Turrentine MW, Brown JW. Surgical results of arterial switch operation for Taussig-Bing anomaly: is position of the great arteries a risk factor? Ann Thorac Surg 2007;83:1451-7.

14. Sinzobahamvya N, Blaschczok HC, Asfour B, Arenz C, Jussli MJ, Schindler E, et al. Right ventricular outflow tract obstruction after arterial switch operation for the Taussig-Bing heart. Eur J Cardiothorac Surg 2007;31:873-8.

15. Prifti E, Crucean A, Bonacchi M, Bernabei M, Murzi B, Luisi SV, et al. Early and long term outcome of the arterial switch operation for transposition of the great arteries: predictors and functional evaluation. Eur $\mathrm{J}$ Cardiothorac Surg 2002;22:864-73.

16. Losay J, Touchot A, Serraf A, Litvinova A, Lambert V, Piot JD, et al. Late outcome after arterial switch operation for transposition of the great arteries. Circulation 2001;104:121-6.

17. Lange R, Cleuziou J, Hörer J, Holper K, Vogt M, TassaniPrell P, et al. Risk factors for aortic insufficiency and aortic valve replacement after the arterial switch operation. Eur J Cardiothorac Surg 2008;34:711-7.

18. Schwartz ML, Gauvreau K, del Nido P, Mayer JE, Colan SD. Long-term predictors of aortic root dilation and aortic regurgitation after arterial switch operation. Circulation 2004; 110:128-32.

19. Marino BS, Wernovsky G, Kreb DL, Mantel SF, van der Woerd WL, Visser D, et al. Neo-aortic root dilation and regurgitation are progressive following the arterial switch operation. J Am Coll Cardiol 2002;39(Suppl 2):413.

20. Erek E, Yalçınbaş YK, Salihoğlu E, Öztürk N, Soybir N, Sarığlu A, et al. Büyük arterlerin transpozisyonunda arteryel switch sonrası reoperasyonlar. Turk Kardiyol Dern Ars 2002;30:544-8. 
21. McMahon CJ, Ravekes WJ, Smith EO, Denfield SW, Pignatelli RH, Altman CA, et al. Risk factors for neo-aortic root enlargement and aortic regurgitation following arterial switch operation. Pediatr Cardiol 2004;25:329-35.

22. Tchervenkov CI, Marelli D, Béland MJ, Gibbons JE, Paquet M, Dobell AR. Institutional experience with a protocol of early primary repair of double-outlet right ventricle. Ann Thorac Surg 1995;60:610-3.
23. Sarığlu T, Kınoğlu B, Bilal MS, Sarıŏlu A, Sağbaş E, Yalçınbaş YK ve ark. Arteriyel switch ameliyatlarında koroner arterlerin translokasyon metodları. GKC Cer Derg 1997;5:88-97.

24. Erek E, Yalcinbas YK, Turkekul Y, Saygili A, Ulukol A, Sarioglu A, et al. Indications and risks of delayed sternal closure after open heart surgery in neonates and early infants. World J Pediatr Congenit Heart Surg 2012;3:229-35. 